\title{
ANALISIS STRUKTUR DAN KAIDAH KEBAHASAAN TEKSCERITA IMAJINASI DALAM PEMBELAJARAN BAHASA INDONESIA SISWA KELAS VII SMP NEGERI 2 PANGURURAN
}

\author{
Charli Guru Singa ${ }^{1}{ }^{1}$ Asnita Hasibuan ${ }^{2}$ \\ *1. Penulis \\ *2. Pembimbing \\ Program Studi Pendidikan Bahasa Indonesia,FakultasKeguruan dan Ilmu Pendidikan, Universitas Katolik \\ Santo Thomas, Jl. Setia Budi No. 479-F Tanjung Sari Medan - Kode Pos No. 20132, email- \\ gurusingacharli@yahoo.co.id
}

\begin{abstract}
Abstrak
Penelitian ini bertujuan untuk mendeskripsikan (1) struktur teks cerita imajinasi siswa kelas VII SMP Negeri 2 Pangururan Tahun Pelajaran 2018/2019; (2) kaidah kebahasaan teks cerita imajinasi siswa kelas VII SMP Negeri 2 Pangururan Tahun Pelajaran 2018/2019. Pendekatan kualitatif digunakan peneliti dengan subjek penelitian, siswa kelas VII-1 SMP Negeri 2 Pangururan Tahun Pelajaran 2018/2019 yang berjumlah 32 orang. Teknik pengumpulan data peneliti adalah teknik analisis dokumen. Sumber data penelitan ini adalah teks cerita imajinasi siswa kelas VII-1 SMP Negeri 2 Pangururan Tahun Pelajaran 2018/2019. Dari 32 data dianalisis, sebanyak 32 (100\%) siswa mampu dengan baik menemukan ketiga struktur cerita imajinasi "Para Peri dan Pembuat Sepatu". Pada bagian resolusi $31(96,87 \%)$ siswa sudah mampu menemukan struktur. Hanya 1 (3,12\%) siswa belum bisa menemukan dengan baik struktur bagian resolusi. Sebanyak 30 (93,75\%) siswa mampu menemukan bahasa tidak formal, 27 (84,37\%) siswa mampu menemukan kata ganti orang, $13(40,62 \%)$ siswa mampu menemukan kata cerapan pancaindera, $20(62,5 \%)$ siswa mampu menemukan kata sambung penanda urutan waktu, $17(53,12 \%)$ siswa mampu menemukan kata/ungkapan keterkejutan, 20 (62,5\%) siswa mampu menemukan kalimat langsung. Sebanyak $5(15,62 \%)$ siswa yang mampu menemukan sruktur dan kaidah kebahasaan teks cerita imajinasi "Para Peri dan Pembuat Sepatu"
\end{abstract}

Kata Kunci: analisis, struktur dan kaidah kebahasaan teks cerita imajinasi

\begin{abstract}
This study aims to describe (1) the structure of the imagination story text of grade VII students of SMP Negeri 2 Pangururan Academic Year 2018/2019; (2) linguistic rules text of imagination stories for grade VII students of SMP Negeri 2 Pangururan Academic Year 2018-1919. Qualitative approaches are used by researchers with research subjects, students of class VII-1 of SMP Negeri 2 Pangururan 2018/2019 Academic Year totaling 32 people. Researcher data collection techniques are document analysis techniques. The source of this research data is the text of the imagination of students of class VII-1 of SMP Negeri 2 Pangururan in 201/2019 Academic Year. Of the 32 data analyzed, as many as $32(100 \%)$ students were able to find the three story structures of the imagination of "Elves and Shoe Makers" well. In resolution $31(96.87 \%)$ students have been able to find the structure. Only 1 $(3.12 \%)$ students have not been able to find the structure of the resolution section properly. As many as $30(93.75 \%)$ students were able to find informal language, 27 (84.37\%) students were able to find the pronoun person, $13(40.62 \%)$ students were able to find the word sensory perception, $20(62.5 \%)$ students were able to find conjunctions of time markers, 17 ISSN 15421-71667
\end{abstract}

Volume 1 Nomor 1 Desember 2018 
(53.12\%) students were able to find words / expressions of surprise, 20 (62.5\%) students were able to find sentences directly. As many as $5(15.62 \%)$ students were able to find structures and linguistic rules text imaginary story of "Elves and Shoe Makers"

\section{Keywords: analysis, linguistic structure and rules text imagination stories}

\section{PENDAHULUAN}

Dunia pendidikan sudah pasti tidak lepas dari proses belajar mengajar antara pendidik dan peserta didik. Bertahannya pengajaran di sekolah saat ini dikarenakan pengajaran mempunyai peran yang sangat penting dalam mencapai aspek dan tujuan dari pendidikan. Pengajaran sastra merupakan bagian dari program pengajaran bahasa sesuai dengan tuntutan kurikulum. Pengajaran sastra ini ditentukan: watak, sikap dan tingkah laku seseorang dalam kehidupan di masyarakat. Untuk setiap langkah pengajaran di sekolah perlu dibuktikan keberhasilannya. Pengajaran sastra sangat penting diajarkan dalam proses pendidikan karena melalui pengajaran yang seperti ini siswa mampu mengetahui kemampuannya dalam berkarya atau membuat sesuatu yang bermanfaat. Sehingga siswa mampu mengekspresikan kemampuan daya imajinasinya untuk berkarya, misalnya membuat cerpen, pantun, puisi, novel.

Buku paket Bahasa Indonesia yang diterbitkan pemerintah, baik untuk pegangan pendidik maupun pegangan peserta didik, yang menjadi penunjang dalam proses pembelajaran. Dalam buku Bahasa Indonesia Kurikulum 2013 SMP/MTs Kelas VII Kompetensi Dasar 3.4 Menelaah struktur dan kebahasaan dari teks cerita imajinasi yang dibaca dan dengar. Pembahasan ini akan mempelajari mengenai struktur dan kaidah kebahasaan yang terdapat pada teks cerita imajinasi.Dengan adanya buku siswa mempermudah guru untuk menyampaikan materi pembelajaran dari buku Bahasa Indonesia salah satunya teks cerita imajinasi.
Peningkatan mutu pengajaran
memang tidak bisa lepas dari usaha meningkatkan apresiasi siswa terhadap karya sastra itu sendiri. Pada pengajaran karya sastra dapat digolongkan menjadi tiga macam, yaitu prosa, puisi, dan drama. Bentuk kesusastraan yang paling banyak digemari adalah jenis karya sastra prosa khususnya teks fantasi dikarenakan memiliki ciri khasnya tersendiri. Jenis karya sastra ini semakin dekat di hati masyarakat sejalan dengan perkembangan teknologi informasi dan komunikasi.

Cerita imajinasi merupakan sebuah karya tulis yang dibangun menggunakan alur cerita yang normal, namun memiliki sifat imajinatif atau khayalan. Umumnya unsur-unsur dan struktur cerita imajinasi ini seperti tema, sudut pandang, setting, alur, penokohan, konflik, ending, dan lain sebagainya dibuat berlebihan dan terkesan tidak akan pernah terjadi pada dunia nyata.

Teks cerita imajinasi pada dasarnya termasuk kedalam kategori teks narasi yang merupakan sebuah teks karangan fiksi yang alur atau rangkaian peristiwa umunya menggunakan pola sebab akibat. Narasi merupakan cerita fiksi yang berisi perkembangan peristiwa dalam cerita disebut alur. Meskipun teks ini termasuk dalam karangan fiksi dan bersifat khayalan namun cerita ini umumnya menceritakan perkembangan kejadian atau peristiwa yang berwal dari prolog hingga epilog yang telah melalui beberpa tahapan seperti awal konflik, puncak permasalahan dan penyelesaian. Cerita pada teks ini berkembang pada tahap orientasi (apa, siapa, dan dimana kejadian terjadi) timbul komplikasi, dan penyelesaian/ akhir cerita. Cerita imajinasi yang digemari oleh 
banyak orang, karena isi dari cerpen banyak mengandung nilai kehidupan sehari-hari yang artinya salah satu dari nilai kehidupan dalam masyarakat dikemas menjadi sebuah cerita yang menarik dan penuh konflik. Selain itu cerita imajinasi juga merupakan cerita yang isinya singkat, ekonomis dalam pemakaian kata, sehingga tidak memerlukan waktu yang lama menulisnya maupun untuk membacanya. Apabila dibandingkan dengan karya yang lainnya, seperti novel dan roman, cerpen walaupun singkat tetapi cerita imajinasi mengandung satu kesatuan yang bulat dan utuh.

Menganalisis teks cerita imajinasi sering ditemui beberapa kesulitan dalam prosesnya, pembelajaran pun masih sering mengalami kegagalan. Salah satunya faktor kegagalan sebagai bentuk ketidakmampuan peserta didik dalam menguasai materi pelajaran. Kemampuannya dalam menganalisis teks imajinasi dinilai kurang memadai. Masih banyak peserta didik belum mampu dalam menganalisis teks imajinasi dengan baik dan benar. Maka dari itu, salah satu cara agar peserta didik dapat menganalisis teks cerpen dengan baik dan benar yaitu peserta didik harus mengikuti prosedur pada pelajaran yang disampaikan guru. Baik buruknya suatu mutu pembelajaran di sekolah, tidak lepas dari metode pembelajaran yang menunjang keefektifan dalam proses penyampaian materi ataupun bahan ajar.

Berdasarkan persoalan tersebut
penulis tertarik untuk melakukan
penelitian tentang analisis struktur dan
kaidah teks cerita imajinasi dalam
pembelajaran bahasa Indonesia siswa kelas
VII SMP Negeri 2 Pangururan tahun
pelajaran 2018/2019.

\section{KAJIAN KEPUSTAKAAN}

Untuk memperkuat hasil temuan dalam suatu penelitian tidak lepas dari teori-teori yang besifat objektif. Semakin objektif teori yang dipergunakan seorang peneliti dalam suatu penelitian maka hasil yang diperoleh pada suatu penelitian yang akan dilakukan lebih bermutu. Maka dari itu peneliti yang baik adalah peneliti yang didasarkan atas suatu teori.

\section{Pengertian Analisis}

Menurut Gorys Keraf, analisis adalah sebuah proses untuk memecahkan sesuatu kedalam bagian-bagian yang saling berkaitan satu sama lainnya.Analisis kesalahan merupakan suatu prosedur kerja yang biasa digunakan untuk para peneliti dan gurubahasa, yang meliputi pengumpulan sampel, penjelasan kesalahan, pengklasifikasian kesalahan berdasarkan penyebabnya, serta pengevaluasian atau penilaian taraf keseriusan kesalahan itu (Ellis dalam Tarigan,2011: 60-61).

\section{Fungsi dan Tujuan analisis}

Secara umum analisis mempunyai fungsi untuk mengumpulkan data-data yang terdapat pada suatu lingkungan tertentu. Analisis dapat diterapkan diberbagai jenis lingkungan dan keadaan. Analisis akan lebih optimal dipergunakan dalam keadaan kritis dan untuk keadaan yang membutuhkan strategi. Karena analisis dapat mengetahui secara mendetail tentang keadaan lingkungan saat ini.

Analisis bertujuan untuk mengumpulkan data yang pada ahkirnya data-data ini dapat dipergunakan untuk berbagai keperluan pelaku analisis. Biasanya akan digunakana dalam menyelesaikan krisis atau konflik.

\section{Struktur Teks Cerita Imajinasi}

Menurut E. Kosasih (2014: 113) menyatakan bahwa struktur cerita pendek dibentuk oleh (1) orientasi atau pengenalan cerita, baik itu berkenaan dengan penokohan ataupun bibit-bibitnya masalah yang dialaminya. (2) komplikasi atau 
puncak konflik, yakni bagian cerpen yang menceritakan puncak masalah yang dialami tokoh utama. Masalah itu tentu saja tidak dikehendaki oleh sang tokoh. Bagian ini pula yang paling menegangkan dan rasa penasaran pembaca tentang cara sang tokoh di dalam menyelesaikan masalahnya bisa terjawab. Dalam bagian ini, tokoh menghadapi dan menyelesaikan masalah itu yang kemudian timbul konsekuensi atau akibat-akibat tertentu yang meredakan masalah sebelumnya. (3) resolusi merupakan tahap penyelesaian akhir dari seluruh rankaian cerita. Bedanya dengan komplikasi, pada bagian ini ketegangan sudah lebih mereda. Dapat dikatakan pada bagian ini hanya terdapat masalah-masalah kecil yang tersisa yang perlu mendapat penyelesaian.Sementara itu, Titi Harsiati, Agus Trianto, dan E. Kosasih (2013: 60) menjelaskan tentang struktur teks fantasi, yaitu (1) orientasi: bagian awal yang berisi pengenalan tokoh, latar tempat, suasana, dan waktu serta awalan masuk ke tahap berikutnya; (2) komplikasi; bagian dimana tokoh dalam cerita berhadapan dengan masalah, timbul hingga masalah memuncak (3) resolusi: bagian ini merupakan kelanjutan dalam komplikasi, yaitu penyelesaian masalah.

\section{Kaidah Kebahasaan Teks Cerita Imajinasi}

\section{a. Ragam Bahasa Tidak Formal}

Ragam bahasa yang dipergunakan dalam teks cerita imajinasi biasanya tidak formal. Misalnya, berupa percakapan sehari-hari. Selain itu kalimat di dalamnya variatif dan ekspresif.

Contoh:

1. "Bu Guru tadi meminta kami bercerita di depan kelas," kata Murkit setelah menghirup kuah supnya sampai habis.

2. "Masakan ibu semuanya enak," kata Murkit penuh semangat.
3. "Nah, ini adalah gilingan bawang dan merica. Ayo kita tumis bumbu ini di kuali," kata Ibu.

\section{b. Kata Ganti Orang}

Penggunaan kata ganti orang dan nama orang sebagai sudut pandang penceritaan (aku, mereka, dia, Bonar, Poltak, dll). Pronomina merupakan kategori yang berfungsi untuk menggantikan nomina (Kridalaksana, 2008: 76). Sedangkan menurut Asep Ganda Sadikin,dkk 2017: 48, Kata ganti adalahkata yang berfungsi menggantikan orang, atau sesuatu yang dibendakan. Kata ganti orang terdiri atas beberapa kategori.

\begin{tabular}{|l|l|l|l|}
\hline Jumlah & $\begin{array}{l}\text { Kata } \\
\text { ganti } \\
\text { orang } \\
\text { pertama }\end{array}$ & $\begin{array}{l}\text { Kata } \\
\text { ganti } \\
\text { orang } \\
\text { kedua }\end{array}$ & $\begin{array}{l}\text { Kata } \\
\text { ganti } \\
\text { orang } \\
\text { ketiga }\end{array}$ \\
\hline Tunggal & $\begin{array}{l}\text { Aku, } \\
\text { saya }\end{array}$ & $\begin{array}{l}\text { Kamu, } \\
\text { anda }\end{array}$ & Dia, ia \\
\hline Jamak & Kami,kita & Kalian & Mereka \\
\hline
\end{tabular}

Kata ganti orang juga bisa ditandai dengan penggunaan sebutan atau nama.

Contoh:

1. Murkit Si peri ecil duduku manis di meja makan.

2. Ia beranjak dari kursinya, menerapikan meja makan dengan lambaian tangannya.

3. Aku ingin pintar seperti mereka, ibu.

4. Kamu adalah anak ibu yang istimewa, Murkitku.

5. Mereka beterbangan ke sana kemari sambil berbisik-bisik masakan apa yang harus mereka buat untuk perlombaan nanti.

6. Aku dan Ibu akan membuat sup andalan kami yang enak, seru murkit dalam hatinya. 
7. Loti anak pintar. Dia selalu mendapat nilai tinggi di kelas.

\section{c. Kata Cerapan Pancaindra Pengimajian)}

\begin{abstract}
Pencitraan digunakan untuk memberi gambaran yang jelas, menimbulkan suasana yang khusus, membuat hidup (lebih hidup) gambaran dalam pikiran dan penginderaan, untuk menarik perhatian, memberikan kesan, mental atau bayangan visual penyair menggunakan gambaran-gambaran angan.
\end{abstract}

Citraan (imagery) merupakan gambaran angan dalam puisi yang ditimbulkan melalui kata-kata. Ada bermacam-macam jenis citraan, sesuai dengan indera yang dihasilkannya, yaitu (1) citra penglihatan (visual imagery) (2) citraan pendengaran (auditory imagery) (3) citra rabaan (thermal imagery) (4) citra pengecapan (tactile imagery) (5) citraan penciuman (olfactory imagery) (6) citraan gerak (kinestheti imagery).

Kata cerapan pancaindera adalah kata sifat yang bertalian dengan penglihatan, pendengaran, penciuman, perabaan, dan pencitraan (Asep Ganda Sadikin,dkk 2017: 49), yaitu: 1) Penglihatan $\rightarrow$ gelap, terang, suram merdu.

2) Pendengaran $\rightarrow$ sunyi, bising,

3) Penciuman $\rightarrow$ wangi, busuk, semerbak. halus,kasar.

4) Perabaan $\rightarrow$ basah, kering,

5) Pencitrasaan $\rightarrow$ manis, asam, lezat, enak.

Contoh:
1. Penglihatan: Murkit mengerling ke arah jendela. Huja ternyata sudah reda. Ia melihat seberkar busur pelangi yang berwarna-warni.

2. Pendengaran: Taman sekolah kini dipenuhi riuh rendah tepuk tangan semua peri.

3. Penciuman: "Bu Guru tadi meminta kami bercerita di depan kelas," kata Murkit setelah menghirup kuah supnya sampai habis.

4. Perabaan: ia mengaduk dua cangkir cokelat panas yang diletakkannya di dekat vas berisikan bunga hostensia biru.

5. Pencitraan: Aku dan Ibu akan membuat sup andalan kami yang enak, seru murkit dalam hatinya.

\section{d. Kata Sambung Penanda Urutan Waktu}

Kata sambung tidak dapat lepas dari sebuah wacana yang dimana kata ini berfungsi untuk menghubungkan satuan yang berupa kalimat, klausa, frase,dan mungkin pula berupa kata-kata sehingga terbentuk sebuah teks wacana.

Kata sambung penanda waktu adalah kata-kata yang menyambungkan hubungan waktu dalam kalimat atau paragraf (Asep Ganda Sadikin,dkk 2017: 48).

Contoh: Penggunaan kata: setelah itu, ketika, sebelum, dan kemudian, dsb.

1. Ketika Murkit akan pergi tidur. Ayah masuk ke kamarnya. Ayah menyelimuti Murkit dan mencium kelopak matanya.

2. Tak lama kemudian, sup pun mendidih.

3 Ibu dan Ayah memeluk dan mencium Murkit. Mereka bangga sekali padanya.

Penggunaan kata sambung urutan waktu untuk menandakan datangnya tokoh lain atau perubahan latar, baik latar 
suasana, waktu, dan tempat (Titi Harsiati, Argus Trianto, dan E. Kosasih, 2013: 67). Contoh: "dua tahun kemudian, Bonar telah sampai di Planet Mars dan bertemu dengan Sahat". Akhirnya, bonar dapat menyelamatkan diri dari terkaman raksasa.

\section{e. Kata/ Ungkapan Keterkejutan}

Menurut KBBI Ungkapan adalah kelompok kata atau gabungan kata yang menyataka makna khusus (makna unsurunsurnya sering kali menjadi kabur). Asep Ganda Sadikin,dkk 2017: 49, istilah kata ungkapan keterkejutan berfungsi untuk menggerakkan cerita dan menimbulkan cerita yang seru. Dapat disimpulkan bahwa ungkapan adalah gabungan kata yang menghasilkan makna baru makna kias).Gabungan kata dalam ungkapan tidak bisa disisipi kata lain.

Contoh:

1. Buah ranum yang bersemu merah: wajahnya yang dihiasi senyum

2. Keras kepala : kepala batu "Karena sifanya yang keras kepala, ayah dan ibu tidak lagi memaksaka kehendak kepada kakak."

3. Gulung tikar : bangkrut

"Akibat tidak ada lagi konsumen yang percaya pada produknya, perusahaan ayah kini gulung tikar."

\section{f. Kalimat Langsung/ Dialog}

Kalimat langsung/ dialog adalah ucapan seseorang secara langsung yang ditulis dalam tanda kutip (Asep Ganda Sndikin,dkk 2017: 50). Misalnya "Masakan ibu semuanya enak," kata Murkit penuh semangat.

Kalimat langsung adalah kalimat yang menirukan ucapan atau ujaran orang lain. Kalimat hasil kutipan pembicaraan seseorang persis apa yang dikatakanya. Bagian ujaran/ ucapan diberi tanda petik
(“....") dapat berupa kalimat perintah, berita, atau kalimat tanya (Kamus Besar Bahasa Indonesia)

Frasa kata atau pun gabungan kata hanya dapat dikategorikan kedalam kalimat apabila memnuhi 5 ciri kalimat yaitu memilik makna, disusun dengan mengikuti kaidah penyusunan tertentu, dapat berdiri sendiri, memiliki jeda, dan diakhiri dengan sebuah intonasi.

Aturan dalam penulisan kalimat langsung:

- Pada kalimat petikan harus diapit menggunakan tanda baca petik dua (")

- Tanda petik dua pada bagian akhir atau pentup berada setealh tanda baca seperti titik (. ) atau koma (, ) dan sebagainya. Sebagai contoh penggunaan tanda petik sebagai berikut:

Ayah mengatakan "Aku akan mengambil cuti bulan depan."

Mobil yang bagus." kata Guntur

Contoh kalimat langsung:

1. "Masakan Ibu semuanya enak," kata Murkit penuh semangat.

2."Bu Guru tadi meminta kami bercerita di depan kelas," kata Murkit setelah menghirup kuah supnya sampai habis.

3. "Nah, ini adalah gilingan bawang dan merica. Ayo kita tumis bumbu ini di kuali," kata Ibu.

\section{Teks Cerita Imajinasi}

Teks merupakan suatu kesatuan bilamana ungkapan bahasa oleh para peserta komunikasi dialami sebagai suatu kesatuan yang bulat. Secara semantik sebuah teks harus memperlihatkan keberuntutan dan harus relevan. Demikian juga semantik/isi yang dituntut sebuah teks ialah tema global yang melingkupi semua unsur. Menurut (Mahsun 2013: 1) 
mengatakan teks merupakan jalan menuju pemahaman tentang bahasa. Nurgiyantoro (2012: 2) menjelaskan bahwa isitiah fiksi sering dipergunakan dalam pertentangannya dengan realitas sehingga kebenarannya dapat dibuktikan dengan data empiris. Teks cerita fiksi merupakan cerita rekaan tentang peristiwa- peristiwa yang didasarkan pada angan-angan atau fantasi, bukan berdasarkan fakta atau kejadian yang sesungguhnya, hanya berdasarkan rekaan pengarang saja. Tokoh, peristiwa, dan latar yang dipergunakan juga bersifat imajinatif. Pada cerita fantasi sesuatu hal yang tidak mungkin dijadikan biasa.

Cerita imajinasi dipahami seebagai cerita yang menampilkan tokoh, alur, atau tema yang derajat kebenarannya diragukan, baik menyangkut (hampir) seluruh maupun hanya sebagian cerita ( Burhan Nurgiyantoro, 2013: 20). Adapun ciri- ciri umum teks cerita imajinasi dapat diketahui melalui ide cerita, mengandung kemisteriusan, latar, tokoh unik, sifat fiktif, bahasa. Ide dalam sebuah cerita fantasi tidakah dibatasi pada kehidupan nyata. Ide cerita fantasi terbuka pada daya khalan/imajinasi penulis. Latar yang digunkan melintasi ruang dan waktu. Tokoh dalam cerita fantasi biasanya memiliki kekuatan super, watak, dan ciri unik yang tidak ada dalam kehidupan sehari-hari. Bahasa yang dipergunakan pun variatif, eksfresif, dan bukan bahasa nonformal (Harsiati, Argus, dan Kosasih, 2016: 51-52).

\section{Jenis-Jenis Cerita Imajinasi}

Jenis sastra anak yang dapat dikelompokkan ke dalam imajinasi ini adalah cerita imajinasi, cerita imajinasi tingkat tinggi, dan fiksi sains Lukens, Huck, dkk (Burhan Nurgiyantoro, 2013: 297).

a. Cerita Imajinasi

Cerita imajinasi menampilkan cerita yang derajat kebenarannya diragukan.
Kebenaran disini dikaitkan dengan logika realitas sebagaimana halnya yang ada dan terjadi dalam kehidupan nyata.

b. Cerita Imajinasi Tinggi

Cerita imajinasi ini memiliki karakteristis, yaitu bahwa apa yang dikisahkan lebih merupakan tokoh dan peristiwa fantastik luar biasa yang kadar kebenarannya diragukan.

\section{c. Fiksi Sains}

Cerita fiksi sains adalah sebuah fiksi yang mengaitkan anatara fakta dan teknologi ilmiah dengan cerita fiksi yang bersifat imajinatif.

\section{Metode}

Penelitian ini menggunakan pendekatan kualitatif, yaitu sebuah pencarian fakta dengan interpretasi yang tepat.Bogdan \& Taylor ( Moleong, 2016: 4) mengatakan bahwa, " Metodologi kualitatif sebagai prosedur penelitian yang menghasilkan data deskriptif berupa katakata tertulis atau lisan dari orang-rang dan perilaku yang dapa diamati”. Pendekatan kualitatif dipilih karena masalah yang diteliti berupa karangan yang dijelaskan dengan menggunakan kata- kata.

\section{HASIL PENELITIAN DAN PEMBAHASAN}

Beberapa deskripsi data dan temuan penelitian di atas dari 32 hasil lembar kerja siswa yang dianalisis oleh peneliti, maka $32(100 \%)$ siswa mampu menemukan dengan baik bagian orientasi dan komplikasi cerita imajinasi "para peri dan pembuat sepatu". Siswa yang belum mampu menemukan struktur dari teks cerita imajinasi "Para Peri dan Pembuat Sepatu" terdapat $1(3,12 \%)$ siswa pada bagian resolusi, $31(96,87 \%)$ siswa sudah mampu menemukan struktur teks cerita imajinasi pada cerita "Para Peri dan Pembuat Sepatu" pada bagian resolusi. 
Sedangkan untuk bagian kaidah kebahasaan teks cerita imajinasi "Para Peri dan Pembuat Sepatu" yang dianalisis oleh peneliti menghasilkan data sebagai berikut: terdapat $30 \quad(93,75 \%)$ siswa mampu menemukan ragam bahasa tidak formal, 27 $(84,37 \%)$ siswa mampu menemukan kata ganti orang, $13(40,62 \%)$ siswa mampu menemukan kata cerapan pancaindera, 20 $(62,5 \%)$ siswa mampu menemukan kata sambung penanda urutan waktu, 17 $(53,12 \%)$ siswa mampu menemukan kata /ungkapan keterkejutan, 20 (62,5\%) siswa mampu menemukan kalimat langsung/ dialog. Adapun permasalahan yang ditemukan peneliti dari lembar kerja siswa masih banyak siswa kurang paham menemukan kaidah kebahasaan teks cerita imajinasi. Berikut akan dijabarkan satu persatu kaidah kebahasaan yang belum ditemukan siswa, sebagai berikut: 2 $(6,25 \%)$ siswa belum mampu menemukan ragam bahasa tidak formal, $5(15,62 \%)$ siswa belum mampu menemukan kata ganti orang, $19(59,37 \%)$ siswa belum mampu menemukan kata cerapan pancaindera, $12(37,5 \%)$ siswa belum mampu menemukan kata sambung penanda urutan waktu, $15(46,87 \%)$ siswa belum mampu menemukan kata/ ungkapan keterkejutan, $12(37,5 \%)$ siswa belum mampu menemukan kalimat langsung/dialog.

Dari 32 jumlah hasil lembar kerja siswa terhadap kemampuan siswa kelas VII-1 SMP Negeri 2 Pangururan, menemukan struktur dan kaidah kebahasaan teks cerita imajinasi "Para Peri dan Pembuat Sepatu" kebanyakan siswa belum mampu menemukan adalah kata cerapan pancaidera, yakni $19(59,37 \%)$ dan struktur hanya $1(3,12 \%)$ siswa yang belum mampu di bagian resolusi. Sedangkan dari antara struktur dan kaidah kebahasaan teks cerita imajinasi tersebut, yang paling sedikit ditemukan adalah ragam bahasa tidak formal, yakni 2 $(6,25 \%)$.
Peneliti menyimpulkan bahwa 32 $(100 \%)$ siswa mampu dengan baik menemukan struktur cerita imajinasi "para peri dan pembuat sepatu" pada bagian orientasi dan komplikasi. Pada bagian resolusi $31(96,87 \%)$ siswa yang mampu menemukan. Hanya $1(3,12 \%)$ siswa tidak menemukan bagian struktur di bagian resolusi. Bagian kaidah kebahasaan teks cerita imajinasi $5(15,62 \%)$ siswa yang sudah mampu menemukan dengan baik. 27 $(84,37 \%)$ siswa yang masih belum mampu untuk menemukan dengan baik kaidah kebahasaan teks cerita imajinasi disebabkan kurang keseriusan dalam belajar dan minimnya masih pengetahuan siswa terutama pada mata pembelajaran berbasis teks cerita imajinasi yang masih baru di programkan pada kurikulum 2013.

\section{SIMPULAN}

a. Dari 32 data hasil lembar kerja siswa VII-1 SMP Negeri 2 Pangururan yang telah dianalisis, peneliti menyimpulkan bahwa sebanyak 32 (100\%) siswa mampu dengan baik menemukan struktur cerita imajinasi "Para Peri dan Pembuat Sepatu" pada bagian orientasi dan komplikasi. Pada bagian resolusi $31(96,87 \%)$ siswa sudah mampu menemukan ketiga struktur dari teks cerita imajinasi "Para Peri dan Pembuat Sepatu", yaitu orientasi atau pengenalan, komplikasi, dan resolusi. Hanya $1(3,12 \%)$ siswa belum bisa menemukan dengan baik ketiga struktur teks cerita imajinasi tersebut.

b. Dari 32 data hasil lembar kerja siswa kelas VII-1 SMP Negeri 2 Pangururan yang dianalisis, peneliti menyimpulkan bahwa sebanyak 30 $(93,75 \%)$ siswa mampu menemukan ragam bahasa tidak formal, 27 $(84,37 \%)$ siswa mampu menemukan kata ganti orang, $13(40,62 \%)$ siswa mampu menemukan kata cerapan pancaindera, $20(62,5 \%)$ siswa mampu menemukan kata sambung penanda 
urutan waktu, $17(53,12 \%)$ siswa mampu menemukan kata /ungkapan keterkejutan, $20 \quad(62,5 \%)$ siswa mampu menemukan kalimat langsung/ dialog. Berikut dijabarkan satu persatu struktur dan kaidah kebahasaan teks cerita imajinasi, sebagai berikut kaidah kebahasaan teks cerita imajinasi, sebanyak 2 $(6,25 \%)$ siswa belum menemukan ragam bahasa tidak formal, 5 $(15,62 \%)$ siswa belum mampu menemukan kata ganti orang, 19 $(59,37 \%)$ siswa belum mampu menemukan kata cerapan pancaindera, $12(37,5 \%)$ belum mampu menemukan kata sambung penanda urutan waktu, $15(46,87 \%)$ siswa belum mampu menemukan kata/ ungkapan keterkejutan, 12 (37,5\%) siswa belum mampu menemukan kalimat langsung/dialog. Sebanyak 5 $(15,62 \%)$ siswa yang mampu menemukan sruktur dan kaidah kebahasaan teks cerita imajinasi "Para Peri dan Pembuat Sepatu"

\section{DAFTAR KEPUSTAKAAN}

Keraf, Gorys. 2002. Eksposisi dan Deskripsi. Jakarta: Nusa Indah

Kosasih, E. 2014. Jenis-Jenis Teks, Analisis Fungsi, Struktur, Dan Kaidah Serta Langkah Penulisannya. Bandung: Yrama Widya

Nurgiyantoro. 2012. Teori Pengkajian Fiksi. Yogyakarta: Gajah Mada University Pess. . 2013. Sastra Anak Pengantar Pemahaman Dunia Anak. Yogyakarta: Gajah Mada University Press.

Mahsun. 2013. Teks dalam Pembelajaran Bahas Indonesia Kurikulum 2013. Jakarta: Rajawali Pers.
Moleong. 2016. Metode Penelitian Kualitatif. Bandung: PT. Remaja Rosdakarya.

Tarigan. 2011. Pengajaran Analisis Kesalahan Berbahasa. Bandung: Angkasa 